\title{
DEVELOPMENT OF N-PHENYL-3-PYRIDIN-2-YL IMINO DERIVATIVES AS ANTICOAGULANTS POTENTIAL FACTOR VIIA INHIBITORS
}

\author{
PRAFULLA B CHOUDHARI *, AND MANISH S BHATIA \\ Drug development sciences research group, \\ Bharati Vidyapeeth College of pharmacy Kolhapur \\ (Received: March 30, 2012 - Accepted: January 13, 2013)
}

\begin{abstract}
The ability of the body to maintain the flow of blood following vascular injury is an important process for the survival. Normally the process of blood clotting and then the subsequent dissolution of the clot, following repair of the injured tissue, is known as hemostasis. Anticoagulants are widely utilized in the treatment of all type of thromboembolism. The present communication deals with the design and docking studies of a series of N-Phenyl-3-Pyridin-2-yl imino analogs and their screening anticoagulants and virtually confirming the mechanism of action as factor VIIa Inhibitors. The compounds were synthesized in excellent yields $(70-80 \%)$ and the structures were established on the basis of consistent IR, 1H NMR, Mass spectroscopy and elemental analysis. All the synthesized compounds were found to exhibit profound anti coagulant activity.
\end{abstract}

Keywords: Anticoagulants, Factor VIIa Inhibition, Docking, QSAR

\section{INTRODUCTION}

The ability of the body to maintain the flow of blood following vascular injury is an important process for the survival. Normally the process of blood clotting and then the subsequent dissolution of the clot, following repair of the injured tissue, is known as hemostasis. Anticoagulants are widely utilized in the treatment of all type of thromboembolism. Due to the limitations of heparin and its derivatives like low-molecular-weight heparin (LMWH), the development of new anticoagulants has been started (1-8). The coagulation cascade can act as an attractive target for the development of newer anticoagulants because involvement of different enzyme and factors in the coagulation process and due to the development in computational chemistry and protein analysis, the structures of all the factors which are involved in coagulation process are known so inhibition of such factors can be act as efficient tool in designing of anticoagulants. The process of coagulation is started with the formation of factor VIIa/tissue factor (TF) complex, which further activates the factors IX and $\mathrm{X}$. The final step of fibrin formation is regulated by the thrombin, which converts fibrinogen to fibrin and then the factor XIII is activated which required for stabilization of the fibrin network by covalently cross linking adjacent fibrin monomers. In literature, the various factor Xa, thrombin inhibitors are reported but now days the attention has been drawn most recently to factor VIIa (FVIIa) because of its role as initiator of the cascade in complex with tissue factor (TF) upon blood vessel damage. The CVS diseases are one of the most common causes of mortality in recent years these diseases are characterized by the myocardial infarction. This inappropriate thrombus formation is initiated via the extrinsic coagulation cascade with the plaque rupture. The plaque rupture exposes tissue factor (TF) to the serine protease factor VIIa (VIIa) in circulating blood, which forms the TF/ VIIa complex. This complex then further activates the serine proteases factors IX to IXa and X to Xa, which in turn activates prothrombin to thrombin and fibrinogen to fibrin. So the selective inhibition of the TF/VIIa complex may provide effective anticoagulation while lessening the risk of bleeding side effects as compared to other antithrombotic mechanisms. FVII is a multidomain protein with a module arrangement similar to FIX, FX, and protein $\mathrm{C}$ which is consist of a serine protease domain, two epidermal growth factor-like domains and a domain rich in g-carboxyglutamic acid (Gla) residues that is Gla domain(9-12). In literature various heterocyclic factor VIIa inhibitors are reported having two heterocyclic wings bridged by amide linkage and having amidine substituent's on the phenyl ring to interact with the aspartic acid 189 which is important amino acid in the binding pocket of factor VIIa. We indented to design the heterocyclic inhibitors without amidine substituent so bleeding side effect of previously reported factor VIIa inhibitors will be minimized. In present communication we deals with design and docking studies of a series of N-Phenyl-3-Pyridin-2-yl imino analogs and their virtual screening as potential factor VIIa Inhibitors.

\section{EXPERIMENTAL}

\section{Target selection:}

Factor VII is an important factor also known as factor VIIa (FVIIa). A serine protease enzyme, coupled with tissue factor (TF) plays an important role in a number of thrombosis-related disorders. Inhibition of TF/FVIIa occurs early in the coagulation cascade and might provide some safety advantages over other related enzymes and the recently developed factor XA inhibitors are lacking in the oral bioavailability and factor VIIa inhibitors can act as choice of drugs in various clotting diseases hence factor VIIa is selected as target for designing of inhibitors.

Cavity Extraction:

Since the catalytic domain of factor VIIa is a trypsin-like serine protease, The active site of factor VIIa has been reported which is comprised of mainly S1, S2, S3, and S' pockets. The amino acids which are showing the crucial interactions were identified that would be important for both potency toward FVIIa and selectivity over other related serine proteases. The catalytic domain of S1pocket consists of the Aspartic acid 189 at the bottom of this pocket and S2 shows the trptophan 215 in the beta-sheet region. Also there is presence of histidine 57 at the S3 pocket and lysine 192 at the S' pocket.

Validation of the active site:

The extracted active site of the factor VIIa is validated using the docking of the reported inhibitors of factor VIIa. The docking results shoes that all the inhibitors were docked in the same site to that of extracted one and the good correlation were observed when graph of docking score and KI were plotted for all the three sets of reported inhibitors The structures of factor VIIa inhibitors are drawn in Vlife MDS and docked in the targeted PDB of factor VIIa using Biopredicta module of Vlife MDS, correction plots of docking score and activity were plotted and correlation is checked

Design of structures:

The active site of the factor VIIa which was extracted and validated using the biopredicta module of the Vlife MDS 3.5.The possible structures which will be acting as the factor VIIa inhibitor with good range of selectivity with compared with the others serine protease in the body were designed. All the reported inhibitors are showing the benzamidine group to show the interaction with the aspartic acid 189 and a planer phenyl ring to bind with the amino acids in the S2 pocket; also the reported inhibitors are having the carboxylic group to capture the positively charged Lys192 residue, a unique feature of factor VIIa. The designed molecules the carboxylic group kept in the form of amine to interact with the positively charged Lys192. The phenyl ring is kept perpendicular to amide for making the vander wall interaction and anchoring the molecule in the S1 Pocket. The electron releasing methyl group is kept in all designed molecules for making the favorable interaction and orientation for interaction with the Trptophan 215 in the beta-sheet region and Histidine 57 in the $\mathrm{S} 3$ pocket

\section{Virtual screening of the designed molecules:}

Various N-phenyl-3-pyridin-2-yl imino derivatives were designed computationally and were docked in to the active site of the factor VIIa (PDB ID: 2BZ6) using the biopredicta module of the Vlife MDS 3.5 software running on the PIV processor.

Synthesis of designed inhibitors

Step no 1: synthesis of ethyl 3-(pyridin-2-ylimino)butanoate

The equimolar quantity of 2- amino pyridine and substituted 2-amino 
pyridine are refluxed with ethyl acetoacetate in presence of glacial acetic acid under microwave irradiation at high power for $15 \mathrm{~min}$. After completion of reaction the flask was cooled to room temperature and the glacial acetic acid was removed. The solid which was obtained was filtered and characterized by melting point, TLC, IR and NMR.

Step no 2: synthesis of $\mathrm{N}$-phenyl-3-(pyridin-2-ylimino)butanamide

The appropriate amine $(0.1 \mathrm{M})$ and $10 \%$ alcoholic $\mathrm{NaOH}(15 \mathrm{ml})$ was taken in round bottom flak. The mixture stirred vigorously and kept under reflux. To this refluxing mixture the solution of imine $(0.1 \mathrm{M})$ in $10 \%$ alcoholic $\mathrm{NaOH}$ was added in equal fraction. The reaction mixture refluxed for 30 minutes, after the completion of reaction the flax cooled to room temperature and mixture of chloroform $(20 \mathrm{ml})$ and water $(20 \mathrm{ml})$ was added. The organic fraction separated and dried at room temperature. The solid obtained characterized by melting point, TLC, IR and NMR

\section{Biological assays of designed molecules}

Determination of prothrombin time (PT) by Quick's method

$0.1 \mathrm{ml}$ of plasma was pipetted out in test tubes and $0.1 \mathrm{ml}$ of brain thromboplastin added to it, and mixed well. The mixture was kept as it was for 2 min and $0.1 \mathrm{ml}$ of pre warmed calcium chloride solution at $37^{\circ} \mathrm{C}$ was added to the test tubes, and the stop watch was started. The test tubes were holed in front of a source of light and after the first appearance of fibrin, the stop watch was stopped; this time was recorded as control reading. For the bioactivity analysis of the samples, $0.1 \mathrm{ml}$ of plasma was pipetted out in test tubes and 0.1 $\mathrm{ml}$ of $100 \mathrm{mg} / \mathrm{ml}$ test compound solution was added to it and mixed well. The test tubes were incubated for $5 \mathrm{~min}$ and the procedure was repeated to record the elongation in mean prothrombin time.

Pharmacophore modelling

This Pharmacophore modelling was carried out in the mol sign module of Vlife MDS 3.5 software. Series of inhibitors was first aligned on the active reported inhibitor; alignment of small organic molecules is one of the important tasks in drug design and bioactivity prediction. A pharmacophore model is a set of three dimensional features that are necessary for bioactive ligands. Thus, it makes logical sense to align molecules based on features that are responsible for bioactivity, the number indicates the minimum number of pharmacophore features generated for an alignment is taken 4 and tolerance is kept to $10 \AA$. The Max Distance Allowed between two features, is placed to 1.

\section{RESULTS AND DISCUSSION}

\section{Target selection and Validation:}

The coagulation cascade is a complex process which is comprised of two pathways with involvement of different factors as given in table no1.From the information obtained from literature, the factor VIIa can prove as a more effective target for the anticoagulant agents than other serine protease in the coagulation cascade. The TF/VIIa complex activates the factor IX and X and triggers the coagulation cascade reaction ultimately resulting in the generation of fibrin clot and thrombin. The inhibition of factor VIIa can minimize the side effects like the bleeding which is associated with other serine protease inhibition and can act as effective treatment in various type of thrombosis. The binding pocket of factor VIIa is validated using structures of reported factor VIIa. The reported factor VIIa inhibitors were docked in the targeted binding pocket of factor VIIa and good correlation is observed within docking score and biological activity which indicates that the targeted binding site of the factor VIIa is useful for pocket modelling studies(figure 2).

\section{Pocket modelling studies:}

The pocket modelling studies were carried out on the proviz module of Vlife MDS 3.5. Proviz is a module for evaluation and visualization of threedimensional molecular properties including those derived from ab initio quantum mechanical wave function obtained through programs like GAMESS and Gaussian. Proviz calculates various molecular properties like the electron density, hydrophilic and lipophilic nature of the molecules. The results of pocket modeling and literature shows that active site of factor VIIa was comprised of aspartic acid 189, serine 195, lysine 192, histidine 57, serine190, tryptophan 215 as core amino acids of the active site (Figure no 1). The inhibitors were designed on the basis of the amino acids which are stated above as well as the amino acids which are in the distance of 5 A0 from active site which include cystine 191 , glycine 216 , glutamic acid 217 , glycine 219 , serine 214 , cystine 220 , and glycine 221 . The active site of factor VIIa is found to be slightly $U$ shaped so complimentary U or V shaped ligand can bind with factor VIIa.

Design of inhibitors

The results of pocket modelling and literature shows that active site of factor VIIa was comprised of aspartic acid 189, serine 195, lysine 192, histidine 57 , serine190, tryptophan 215 , cystine 191 , glycine 216 , glutamic acid 217 , glycine 219 , serine 214 , cystine 220 , glycine 221 . The inhibitors were designed on the basis of pocket modelling data and nature and type of amino acids which are present in the binding site. The reported factor VIIa inhibitors was found to showing the hydrogen bond interaction with the ASP 189 due to presence of the amidine substituent, but these inhibitors are showing problem of bleeding at the site of action, for reducing this problem in designed set of inhibitors the amidine substituent is replaced by the amide linkage which is bound to one aromatic ring on one side and pyridyl ring on the other side of the amide. This modification optimum balance between the reduction of side effects and desired amino acid interactions were achieved (Figure no 3). Carboxylic group in the form of amide linkage in designed molecule found to be giving the interaction with the positively charged lysine 192 which is characteristic feature of factor VIIa because this residue is absent in other serine proteases coagulation cascade. The amide group which is placed in between two rings is playing important role in anchoring the inhibitor in the S1 binding site in factor VIIa.

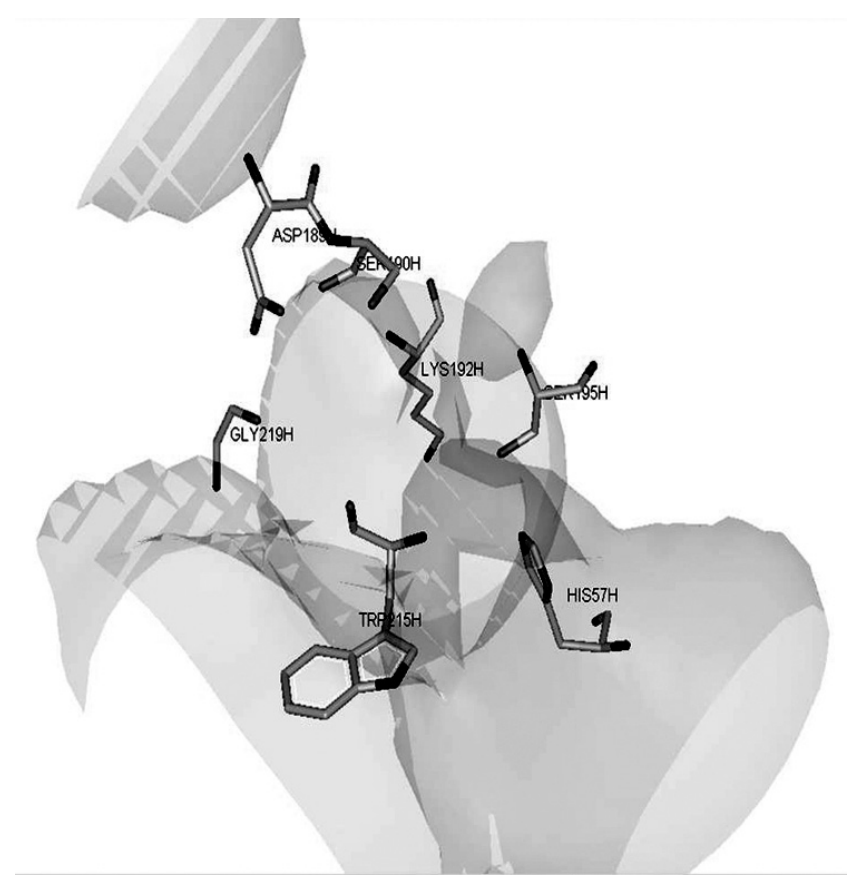

Figure No1: Figure showing shape of binding site of factor VIIa.

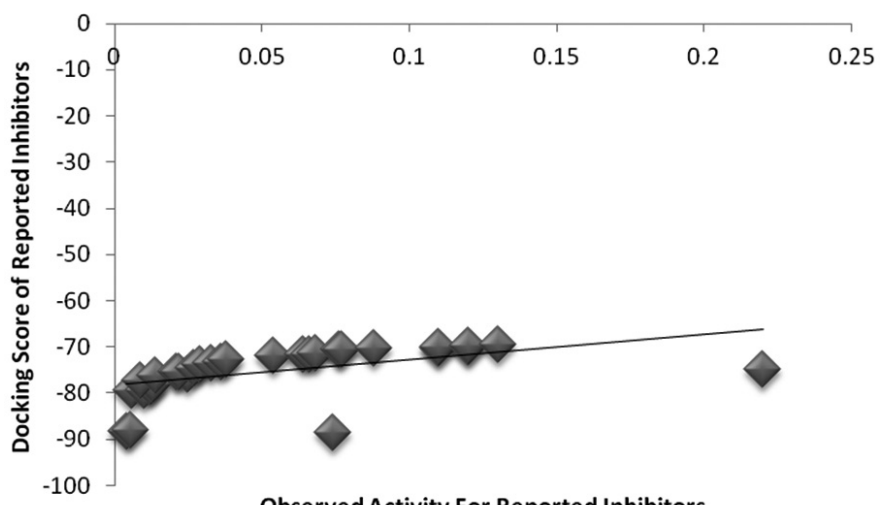

Observed Activity For Reported Inhibitors

Figure No2: Figure showing correlation plot of docking score and experimental activity for reported factor VIIa inhibitors.

\section{Docking analysis of designed inhibitors:}

To check the interaction potential of the designed inhibitors the docking analysis was performed on factor VIIa (PDB ID 2BZ6). All the designed inhibitors were docked in to the same binding site. The designed inhibitors were found to show following interactions; hydrogen bond interaction is 
observed between oxygen of serine (SER214) and hydrogen of alkyl bridge ring with a distance of $2.463 \mathrm{~A} 0$ and nitrogen of pyridyl ring with hydrogen of cystine (CYS 220) 2.054 A0. The four hydrophobic interactions were observed between designed inhibitor (inhibitor no10) tryptophan 215 (TRP215) with a distance of 4.367A0 and glycine (GLY216 and GLY219) with a distance of 4.931 A0 and $4.440 \mathrm{~A} 0$ respectively and with glutamic acid (GLN217) with a distance of $4.836 \mathrm{~A} 0$ (figure no $4 \& 5$ ). PI stacking interaction was observed between designed inhibitors and Histidine 57 (5.364A0). The inhibitors also showed Van der Waals interactions with amino acids like HIS57, GLY97, THR99, ASP189, SER190, CYS191, LYS192, VAL213, SER214, TRP215, GLY216, GLY219, CYS220 and. The interaction with the lysine 192 could be characteristic interaction responsible for selectivity of designed inhibitors towards inhibition of factor VIIa over other serine proteases in body.

\section{SER 195}<smiles>CN=C(C)CC(N)=Nc1ccccn1</smiles>

LYS 192

\section{ASP 189}

Figure No 3: Figure showing the core scaffold of designed inhibitors.

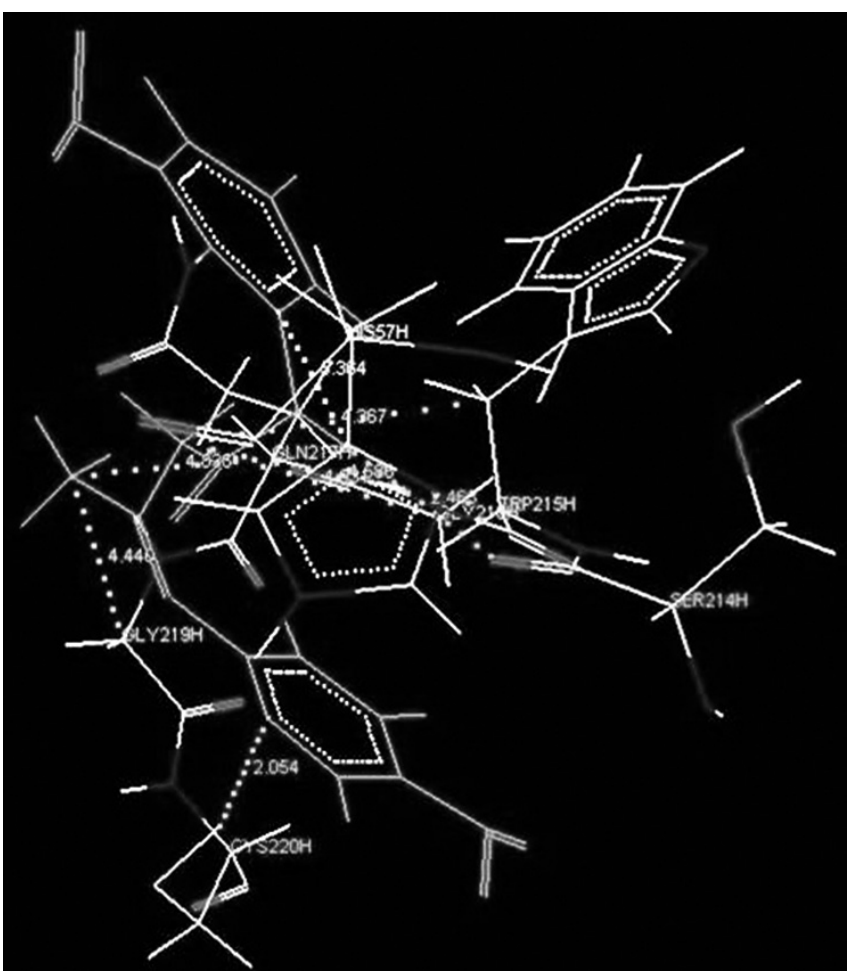
VIIa.

Figure No4: Figure showing the designed inhibitor in active site of factor

PI Stacking Interaction

Hydrophobic Interaction

Hydrogen bond Interaction

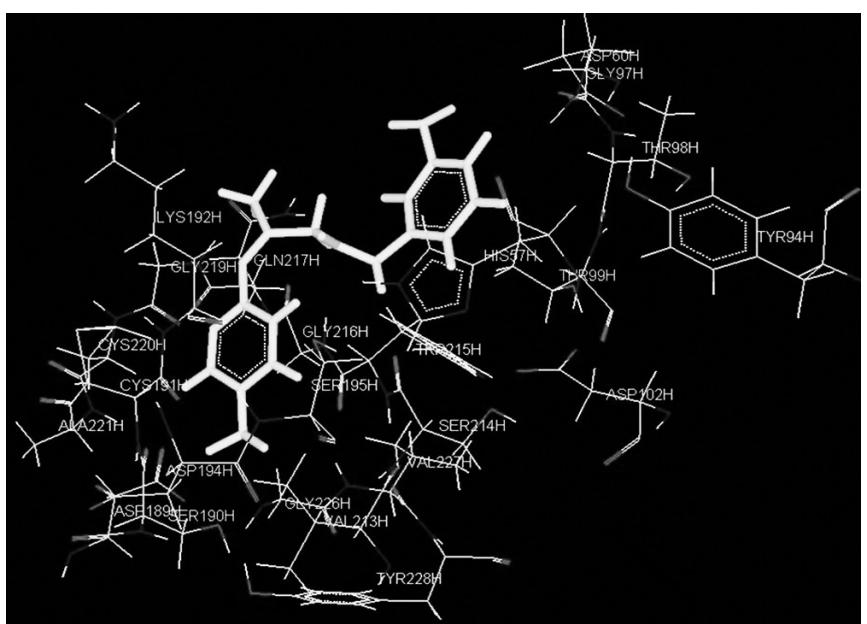

Figure No5: Figure showing the designed inhibitor in active site of factor VIIa.

\section{Chemistry}

The core scaffold utilized for design of inhibitors orient the key functionalities within the enzyme active site required are shown in three in different colour circles. Three key functionalities augmenting the binding within the active site were identified: (a) the amidino group (green) anchoring the inhibitor in the S1 pocket, (b) the carboxyl group for interaction with the Lys192 residue in the pocket, and (c) the pyridine imine (yellow) and electron releasing methyl group for the possible interaction with Try 215 and Gly 219 by formation of Vander wall interaction. These three groups proved to be crucial for maintaining inhibitory potency (figure no 6). The backbone of the designed inhibitors is synthesized by using the 2 amino pyridine as core structure. The 2-amino pyridine is condensed with ethyl acetoacetate to get ethyl 3-(pyridin-2-ylimino) butanoate, in presence of glacial acetic acid. The synthesis of the imine is confirmed by the presence of a strong peak at 1.09 of ester in NMR spectrum. In the second step the ethyl 3-(pyridin-2-ylimino) butanoate is reacted with different substituted amines to get N-phenyl-3(pyridin-2-ylimino) butanamide. The ester is converted in to amide in presence of alcoholic sodium hydroxide. The synthesis of the amide is confirmed by the presence of a strong peak at the $8.0 \mathrm{ppm}$ (amide nitrogen) in the NMR spectrum (Scheme no 1).

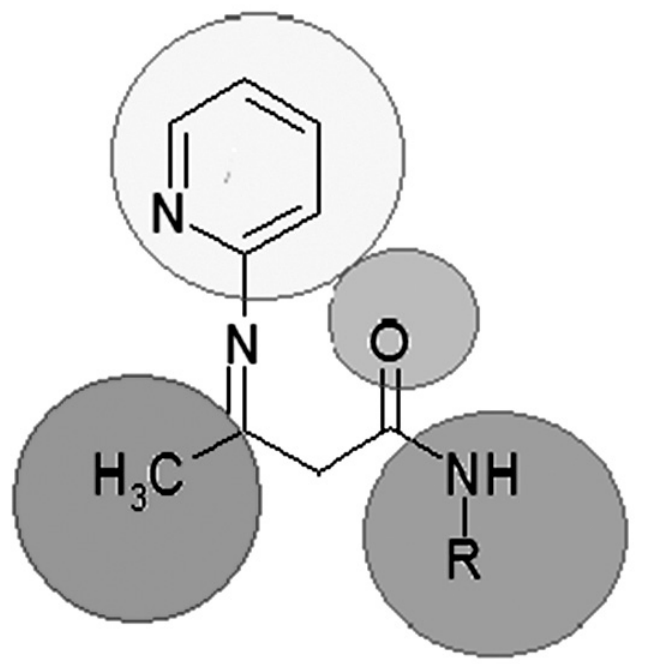

Figure No 6: Figure showing the structure of designed inhibitors. 


\section{Biological assay}

All the designed molecules are showing good anticoagulant activity. The derivatives with the electron with drawing substituent like nitro group are showing the properties of coagulation instead of anticoagulation, due to the unfavourable orientation of the molecules in the enzyme pocket (table no $2 \&$ 3). The derivatives containing the unsubstituted phenyl and amino substituted phenyl rings containing derivatives more active than the derivatives containing nitro substituent's. The nitro substituted derivatives showed the reversible effect than other derivatives they decreased clotting time and acted as coagulants. This indicated that substitution of larger bulkier groups is unfavourable for the activity.

\section{Pharmacophore modelling}

Ten pharmacophore models were generated for the factor VIIa Inhibitory activity. All generated models displayed the same chemical features as two hydrogen bond acceptor (buff colour) and two Hydrophobic (orange colour) and hydrogen bond donor (magenta colour) (figure no 7). The results of the designed pharmacophoric search are validated by comparison with the results of the pharmacophoric search for the reported factor VIIa inhibitors. The two hydrogen bond acceptors (buff colour) are present at $2.23 \mathrm{~A} 0$ apart and the distance between the hydrophobic (orange colour) groups is $5.74 \mathrm{~A} 0$. The molecules are designed by keeping in mind features like the negative ionizable (green colour), who are introduced by the addition of groups like aminidine and amide at the $4^{\text {th }}$ position at the distal phenyl ring.

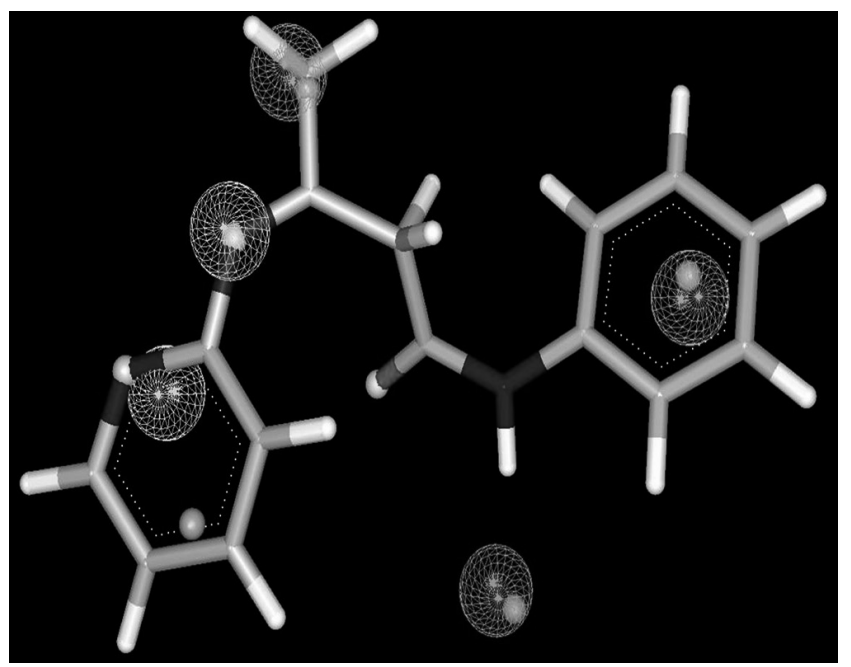

Figure No 7 Figure showing the pharmacophore model for designed inhibitors.
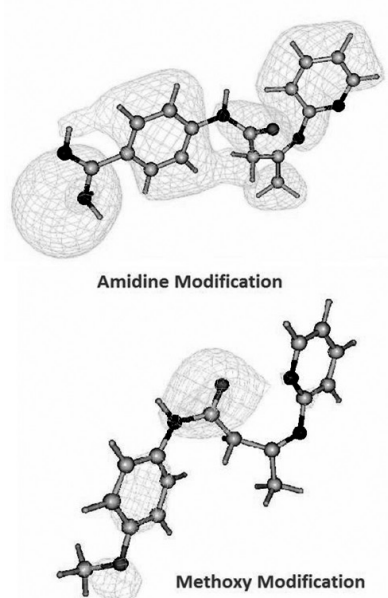

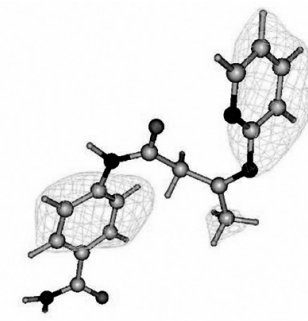

Amide Modification

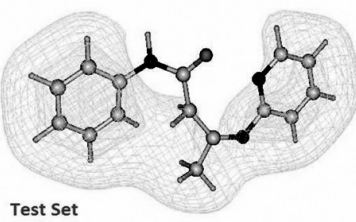

Figure No 8: Figure showing the hydrophobic counters for designed inhibitors.
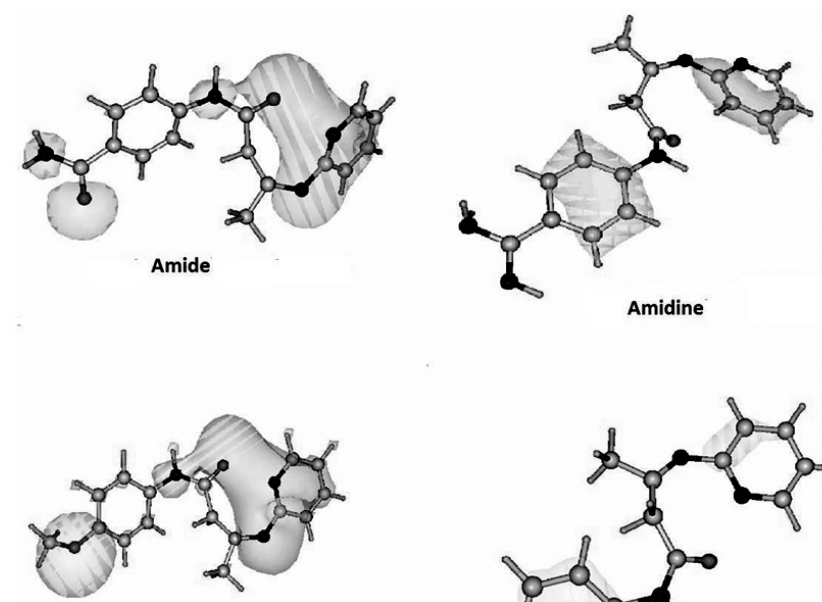

Methoxy

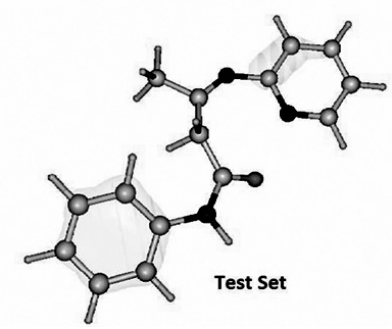

Figure No 9: Figure showing the electrostatic potential counters for designed inhibitors.<smiles>[R]c1ccnc(N)c1[I+]C(C)=O</smiles><smiles>[R]c1ccnc(N=C(C)CC(=O)OCC)c1</smiles><smiles>[R]O[N+]([O-])(O[Na])O[Na]</smiles><smiles>[R][X]NC(=O)CC(C)=Nc1cccnc1</smiles>

Scheme No 1: Scheme of synthesis of designed inhibitors.

Structure-activity relationships

The design of these N-phenyl-3-(pyridin-2-ylimino)butanamide derivatives was made on the basis of the amino acid residue which are present 
in the active site of the factor VIIa and the structures of the reported inhibitors. All the reported factor VIIa inhibitors are containing the features like the distal phenyl ring with the amidine substituent's, these are found to be giving the interaction with the ASP 189 with the formation of pi stacking or hydrogen bond interaction. In this reported research paper, we changed the position of these amidine substituent's the amide bridged the two aromatic rings. This change makes inhibitors to anchors in the enzyme pocket with the formation of the hydrogen bond interaction with serine 214 , also the interaction with Lysine 192. These two interactions are key interaction of designed set of inhibitors which indicates, that the designed inhibitors are selective towards the factor VIIa than other serine proteases as it is interacting with the Lys 192 which is a characteristic feature of factor VIIa. The amide modification also gives an advantage over the amidine derivatives that's of improving the oral bioavailability. All the designed structures are showing good to moderate anticoagulant activity. These results also alerted us to the fact that S2 cavity of fVIIa is highly sensitive even to small changes to the occupying chemical groups. Based upon the better activity of compounds with the compound containing the 2 amino pyridine than compounds containing other modification in 2 amino pyridine and also the size of pocket, we designed two lead molecules with medication in the 4 position to accommodate the interaction at acidic aspartic acid residue at 189 . The modification like amide and amidine are tried and these two derivatives are found to be giving excellent results in virtual screening. These results also alerted us to the fact that $\mathrm{S} 2$ cavity of fVIIa is highly sensitive even to small changes to the occupying chemical groups. Based upon the better activity of compounds with the compound containing the 2 amino pyridine than compounds containing other modification in 2 amino pyridine and also the size of pocket, we designed two lead molecules with modification in the 4 position to accommodate interaction at acidic aspartic acid residue at 189. (Figure $8 \& 9$ ). The new series will be designed on the basis of these results and will be explored extensively in our future communication.

Table No1: Table showing all clotting factors in coagulation cascade.

\begin{tabular}{|c|c|c|}
\hline Factor & Name & Pathway \\
\hline I & Fibrinogen & Both \\
\hline II & Prothrombin & Both \\
\hline III & Tissue Factor & Extrinsic \\
\hline IV & Calcium & Both \\
\hline V & Proaccelerin & Both \\
\hline VI & Accelerin & Both \\
\hline VII & Proconvertin & Extrinsic \\
\hline VIII & Antihemophiliac & Intrinsic \\
\hline IX & Christmas Factor & Intrinsic \\
\hline X & Stuart-Prower Factor & Both \\
\hline XI & Plasmathromboplastin antecedent (PTA) & Intrinsic \\
\hline XII & Hageman Factor & Intrinsic \\
\hline XIII & Protransglutaminase & Both \\
\hline
\end{tabular}

Table no 2: Table showing designed potential factor VIIa inhibitors.

\begin{tabular}{|c|c|c|c|c|c|c|c|c|}
\hline \multirow[b]{2}{*}{$\begin{array}{l}\text { Sr. } \\
\text { No. }\end{array}$} & \multirow[b]{2}{*}{$\mathbf{R}^{6}$} & \multirow[b]{2}{*}{$\mathbf{R}$} & \multirow{2}{*}{ 1HNMR (DMSO-d } & \multicolumn{3}{|c|}{$\begin{array}{l}\text { CHN Analysis } \\
\text { Obe (cal) }\end{array}$} & \multirow[b]{2}{*}{$\operatorname{MS}\left(\mathbf{M}^{+}\right)$} & \multirow[b]{2}{*}{ MP } \\
\hline & & & & C & $\mathbf{H}$ & $\mathbf{N}$ & & \\
\hline 1 & $\mathrm{H}$ & $\mathrm{NH} 2$ & $\begin{array}{c}2.66\left(\mathrm{~s}, 2 \mathrm{H}, \mathrm{CH}_{2}\right) ; 1.94\left(\mathrm{~s}, 3 \mathrm{H}, \mathrm{CH}_{3}\right) ; 7.2- \\
\quad 8.6(9 \mathrm{H}, \text { arom }) ; 7.23(1 \mathrm{H}, \text { amide })\end{array}$ & $\begin{array}{l}71.20 \\
(71)\end{array}$ & $\begin{array}{l}5.12 \\
(6)\end{array}$ & $\begin{array}{c}16.11 \\
(16)\end{array}$ & 252 & $60-64{ }^{\circ} \mathrm{C}$ \\
\hline 2 & $\mathrm{H}$ & 4- $\mathrm{NO}_{2}$ & $\begin{array}{c}2.96\left(\mathrm{~s}, 2 \mathrm{H}, \mathrm{CH}_{2}\right) ; 2.24\left(\mathrm{~s}, 3 \mathrm{H}, \mathrm{CH}_{3}\right) ; 7.8- \\
9.2(8 \mathrm{H}, \text { arom }) ; 7.46(1 \mathrm{H}, \text { amide })\end{array}$ & $60.31(60)$ & $4.52(4.73)$ & $18.60(18.78)$ & 297 & $70-72{ }^{\circ} \mathrm{C}$ \\
\hline 3 & $\mathrm{H}$ & $3-\mathrm{NO}_{2}$ & $\begin{array}{c}2.94\left(\mathrm{~s}, 2 \mathrm{H}, \mathrm{CH}_{2}\right) ; 1.90\left(\mathrm{~s}, 3 \mathrm{H}, \mathrm{CH}_{3}\right) \\
7.22-8.3(8 \mathrm{H}, \text { arom }) ; 7.19(1 \mathrm{H}, \text { amide })\end{array}$ & $60.35(60)$ & $4.60(4.73)$ & $18.55(18.78)$ & 298 & $50-52^{\circ} \mathrm{C}$ \\
\hline 4 & $\mathrm{H}$ & 2- $\mathrm{NO}_{2}$ & $\begin{array}{c}2.99\left(\mathrm{~s}, 2 \mathrm{H}, \mathrm{CH}_{2}\right) ; 2.84\left(\mathrm{~s}, 3 \mathrm{H}, \mathrm{CH}_{3}\right) ; 7.8- \\
9.6(8 \mathrm{H}, \text { arom }) ; 7.43(1 \mathrm{H}, \text { amide })\end{array}$ & $60.33(60)$ & $4.57(4.73)$ & $18.65(18.78)$ & 297 & $68-70^{\circ} \mathrm{C}$ \\
\hline 5 & $\mathrm{H}$ & $4-\mathrm{F}$ & $\begin{array}{c}2.64\left(\mathrm{~s}, 2 \mathrm{H}, \mathrm{CH}_{2}\right) ; 1.89\left(\mathrm{~s}, 3 \mathrm{H}, \mathrm{CH}_{3}\right) ; 7.1- \\
8.4(8 \mathrm{H}, \text { arom }) ; 7.16(1 \mathrm{H}, \text { amide })\end{array}$ & $66.20(66.21)$ & $5.25(5.20)$ & $7.02(7)$ & 271 & $110-112^{\circ} \mathrm{C}$ \\
\hline 6 & $\mathrm{H}$ & $4-\mathrm{CH}_{3}$ & $\begin{array}{c}2.61\left(\mathrm{~s}, 2 \mathrm{H}, \mathrm{CH}_{2}\right) ; 1.88\left(\mathrm{~s}, 3 \mathrm{H}_{,} \mathrm{CH}_{3}\right) ; 7.2- \\
8.1(8 \mathrm{H}, \text { arom }) ; 7.14(1 \mathrm{H}, \text { amide }) ; 2.34 \\
\left(\mathrm{~s}, 3 \mathrm{H}, \mathrm{CH}_{3}\right)\end{array}$ & $71.00(71.79)$ & $6.21(6.41)$ & $15.20(15.72)$ & 266 & $\begin{array}{l}100-102 \\
{ }^{\circ} \mathrm{C}\end{array}$ \\
\hline
\end{tabular}




\begin{tabular}{|c|c|c|c|c|c|c|c|c|}
\hline 7 & $\mathrm{H}$ & $2-\mathrm{Cl}$ & $\begin{array}{c}2.65\left(\mathrm{~s}, 2 \mathrm{H}, \mathrm{CH}_{2}\right) ; 1.95\left(\mathrm{~s}, 3 \mathrm{H}, \mathrm{CH}_{3}\right) ; 7.2- \\
8.8(8 \mathrm{H}, \text { arom }) ; 7.24(1 \mathrm{H}, \text { amide })\end{array}$ & $62.50(62.61)$ & $4.70(4.90)$ & $12.52(12.32)$ & 286 & $110-114^{\circ} \mathrm{C}$ \\
\hline 8 & $\mathrm{H}$ & $4-\mathrm{OCH}_{3}$ & $\begin{array}{c}2.59\left(\mathrm{~s}, 2 \mathrm{H}, \mathrm{CH}_{2}\right) ; 1.87\left(\mathrm{~s}, 3 \mathrm{H}, \mathrm{CH}_{3}\right) ; 7.0- \\
8.0(8 \mathrm{H}, \text { arom }) ; 6.92(1 \mathrm{H}, \text { amide }) ; 3.88(\mathrm{~s} \\
\left.3 \mathrm{H}, \mathrm{OCH}_{3}\right) .\end{array}$ & $67.80(67.83)$ & $6.00(6.05)$ & $14.72(14.83)$ & 283 & $\begin{array}{l}120-124 \\
{ }^{\circ} \mathrm{C}\end{array}$ \\
\hline 9 & $\mathrm{H}$ & $3-\mathrm{CH}_{3}$ & $\begin{array}{c}2.63\left(\mathrm{~s}, 2 \mathrm{H}, \mathrm{CH}_{2}\right) ; 1.90\left(\mathrm{~s}, 3 \mathrm{H}, \mathrm{CH}_{3}\right) ; 7.2- \\
8.4(8 \mathrm{H}, \text { arom }) ; 7.17(1 \mathrm{H}, \text { amide }) ; 2.40 \\
\left(\mathrm{~s}, 3 \mathrm{H}, \mathrm{CH}_{3}\right)\end{array}$ & $71.10(71.79)$ & $\begin{array}{c}6.31 \\
(6.41)\end{array}$ & $15.25(15.72)$ & 267 & $108-110^{\circ} \mathrm{C}$ \\
\hline 10 & $\mathrm{H}$ & $2-\mathrm{CH}_{3}$ & $\begin{array}{c}2.65\left(\mathrm{~s}, 2 \mathrm{H}, \mathrm{CH}_{2}\right) ; 1.96\left(\mathrm{~s}, 3 \mathrm{H}, \mathrm{CH}_{3}\right) \\
\text { 7.22-8.4 }(8 \mathrm{H}, \text { arom }) ; 7.17(1 \mathrm{H}, \text { amide }) \\
2.36\left(\mathrm{~s}, 3 \mathrm{H}_{,} \mathrm{CH}_{3}\right)\end{array}$ & $71.15(71.79)$ & $6.29(6.41)$ & $15.29(15.72)$ & 266 & $112-116^{\circ} \mathrm{C}$ \\
\hline 11 & $\mathrm{H}$ & $2-\mathrm{OCH}_{3}$ & $\begin{array}{c}2.57\left(\mathrm{~s}, 2 \mathrm{H}, \mathrm{CH}_{2}\right) ; 1.85\left(\mathrm{~s}, 3 \mathrm{H}, \mathrm{CH}_{3}\right) ; 7.1- \\
8.6(8 \mathrm{H}, \text { arom }) ; 6.95(1 \mathrm{H}, \text { amide }) ; 3.89(\mathrm{~s}, \\
\left.3 \mathrm{H}, \mathrm{OCH}_{3}\right) .\end{array}$ & $67.83(67.83)$ & $6.10(6.05)$ & $14.62(14.83)$ & 282 & $188-192^{\circ} \mathrm{C}$ \\
\hline 12 & $\mathrm{H}$ & $3-\mathrm{OCH}_{3}$ & $\begin{array}{c}2.59\left(\mathrm{~s}, 2 \mathrm{H}, \mathrm{CH}_{2}\right) ; 1.90\left(\mathrm{~s}, 3 \mathrm{H}, \mathrm{CH}_{3}\right) ; 7.5- \\
9.0(8 \mathrm{H}, \text { arom }) ; 7.2(1 \mathrm{H}, \text { amide }) ; 3.41(\mathrm{~s} \\
\left.3 \mathrm{H}, \mathrm{OCH}_{3}\right) .\end{array}$ & $67.89(67.83)$ & $6.10(6.05)$ & $14.80(14.83)$ & 282 & $200-204^{\circ} \mathrm{C}$ \\
\hline 13 & $5-\mathrm{NO}_{2}$ & $\mathrm{NH}_{2}$ & $\begin{array}{c}2.7\left(\mathrm{~s}, 2 \mathrm{H}, \mathrm{CH}_{2}\right) ; 1.98\left(\mathrm{~s}, 3 \mathrm{H}, \mathrm{CH}_{3}\right) ; 7.26- \\
8.9(78 \mathrm{H}, \text { arom }) ; 7.3(1 \mathrm{H}, \text { amide })\end{array}$ & $60.80(60.40)$ & $4.70(4.73)$ & 18.60(18.78) & 297 & $60-64^{\circ} \mathrm{C}$ \\
\hline 14 & $5-\mathrm{NO}_{2}$ & $4-\mathrm{NO}_{2}$ & $\begin{array}{c}3.2\left(\mathrm{~s}, 2 \mathrm{H}, \mathrm{CH}_{2}\right) ; 2.3\left(\mathrm{~s}, 3 \mathrm{H}, \mathrm{CH}_{3}\right) ; 8.1-9 \\
(7 \mathrm{H}, \text { arom }) ; 7.5(1 \mathrm{H}, \text { amide })\end{array}$ & $52.30(52.48)$ & $3.80(3.82)$ & $20.60(20.40)$ & 342 & $54-56^{\circ} \mathrm{C}$ \\
\hline 15 & $5-\mathrm{NO}_{2}$ & $3-\mathrm{NO}_{2}$ & $\begin{array}{c}3.1\left(\mathrm{~s}, 2 \mathrm{H}, \mathrm{CH}_{2}\right) ; 2.10\left(\mathrm{~s}, 3 \mathrm{H}, \mathrm{CH}_{3}\right) ; 7.09- \\
8.1(7 \mathrm{H}, \text { arom }) ; 7.42(1 \mathrm{H}, \text { amide })\end{array}$ & $52.35(52.48)$ & $3.84(3.82)$ & $20.65(20.40)$ & 342 & $60-62{ }^{\circ} \mathrm{C}$ \\
\hline 16 & $5-\mathrm{NO}_{2}$ & $2-\mathrm{NO}_{2}$ & $\begin{array}{c}2.99\left(\mathrm{~s}, 2 \mathrm{H}, \mathrm{CH}_{2}\right) ; 2.86\left(\mathrm{~s}, 3 \mathrm{H}, \mathrm{CH}_{3}\right) ; 7.8- \\
9.6(7 \mathrm{H}, \text { arom }) ; 7.47(1 \mathrm{H}, \text { amide })\end{array}$ & $52.30(52.48)$ & $3.80(3.82)$ & $20.55(20.40)$ & 342 & $60-64{ }^{\circ} \mathrm{C}$ \\
\hline 17 & $5-\mathrm{NO}_{2}$ & $4-\mathrm{F}$ & $\begin{array}{c}2.67\left(\mathrm{~s}, 2 \mathrm{H}, \mathrm{CH}_{2}\right) ; 1.90\left(\mathrm{~s}, 3 \mathrm{H}, \mathrm{CH}_{3}\right) ; 7.15- \\
8.1(7 \mathrm{H}, \text { arom }) ; 7.19(1 \mathrm{H}, \text { amide })\end{array}$ & $56.10(56.96)$ & $4.15(4.14)$ & $17.60(17.71)$ & 317 & $114-116^{\circ} \mathrm{C}$ \\
\hline 18 & $5-\mathrm{NO}_{2}$ & $4-\mathrm{CH}_{3}$ & $\begin{array}{c}2.63\left(\mathrm{~s}, 2 \mathrm{H}, \mathrm{CH}_{2}\right) ; 1.87\left(\mathrm{~s}, 3 \mathrm{H}, \mathrm{CH}_{3}\right) \\
\text { 7.12-7.9 }(7 \mathrm{H}, \text { arom }) ; 7.10(1 \mathrm{H}, \text { amide }) \\
2.29\left(\mathrm{~s}, 3 \mathrm{H}_{,} \mathrm{CH}_{3}\right)\end{array}$ & $61.40(61.53)$ & $5.10(5.16)$ & $17.70(17.94)$ & 311 & $200-202^{\circ} \mathrm{C}$ \\
\hline 19 & $5-\mathrm{NO}_{2}$ & $2-\mathrm{Cl}$ & $\begin{array}{l}2.68\left(\mathrm{~s}, 2 \mathrm{H}, \mathrm{CH}_{2}\right) ; 1.99\left(\mathrm{~s}, 3 \mathrm{H}, \mathrm{CH}_{3}\right) ; \\
7.30-8.9(7 \mathrm{H}, \text { arom }) ; 7.3(1 \mathrm{H}, \text { amide })\end{array}$ & $54.45(54.15)$ & $3.90(3.94)$ & $16.80(16.84)$ & 333 & $130-134{ }^{\circ} \mathrm{C}$ \\
\hline 20 & $5-\mathrm{NO}_{2}$ & $4-\mathrm{OCH}_{3}$ & $\begin{array}{c}2.61\left(\mathrm{~s}, 2 \mathrm{H}, \mathrm{CH}_{2}\right) ; 1.90\left(\mathrm{~s}, 3 \mathrm{H}, \mathrm{CH}_{3}\right) ; 7.2- \\
8.2(7 \mathrm{H}, \text { arom }) ; 6.95(1 \mathrm{H}, \text { amide }) ; 3.90(\mathrm{~s} \\
\left.3 \mathrm{H}, \mathrm{OCH}_{3}\right) .\end{array}$ & $58.50(58.53)$ & $4.80(4.91)$ & $17.00(17.06)$ & 329 & $170-174{ }^{\circ} \mathrm{C}$ \\
\hline 21 & $5-\mathrm{NO}_{2}$ & $3-\mathrm{CH}_{3}$ & $\begin{array}{c}2.67\left(\mathrm{~s}, 2 \mathrm{H}, \mathrm{CH}_{2}\right) ; 1.93\left(\mathrm{~s}, 3 \mathrm{H}, \mathrm{CH}_{3}\right) ; 7.23- \\
8.5(7 \mathrm{H}, \text { arom }) ; 7.18(1 \mathrm{H}, \text { amide }) ; 2.43 \\
\left(\mathrm{~s}, 3 \mathrm{H}, \mathrm{CH}_{3}\right)\end{array}$ & $61.45(61.53)$ & $5.12(5.16)$ & $17.87(17.94)$ & 313 & $160-164{ }^{\circ} \mathrm{C}$ \\
\hline 22 & $5-\mathrm{NO}_{2}$ & $2-\mathrm{CH}_{3}$ & $\begin{array}{c}2.66\left(\mathrm{~s}, 2 \mathrm{H}, \mathrm{CH}_{2}\right) ; 1.97\left(\mathrm{~s}, 3 \mathrm{H}, \mathrm{CH}_{3}\right) ; \\
7.25-8.4(7 \mathrm{H}, \text { arom }) ; 7.20(1 \mathrm{H}, \text { amide }) ; \\
2.39\left(\mathrm{~s}, 3 \mathrm{H}, \mathrm{CH}_{3}\right)\end{array}$ & $61.55(61.53)$ & $5.18(5.16)$ & $17.80(17.94)$ & 313 & $166-168^{\circ} \mathrm{C}$ \\
\hline 23 & $5-\mathrm{NO}_{2}$ & $2-\mathrm{OCH}_{3}$ & $\begin{array}{c}2.59\left(\mathrm{~s}, 2 \mathrm{H}, \mathrm{CH}_{2}\right) ; 1.86\left(\mathrm{~s}, 3 \mathrm{H}, \mathrm{CH}_{3}\right) \\
\text { 7.15-8.3 }(7 \mathrm{H}, \text { arom }) ; 6.98(1 \mathrm{H}, \text { amide }) \\
3.92\left(\mathrm{~s}, 3 \mathrm{H}, \mathrm{OCH}_{3}\right)\end{array}$ & $58.45(58.53)$ & $4.85(4.91)$ & $17.05(17.06)$ & 329 & $168-170^{\circ} \mathrm{C}$ \\
\hline 24 & $5-\mathrm{NO}_{2}$ & $3-\mathrm{OCH}_{3}$ & $\begin{array}{c}2.60\left(\mathrm{~s}, 2 \mathrm{H}, \mathrm{CH}_{2}\right) ; 1.92\left(\mathrm{~s}, 3 \mathrm{H}, \mathrm{CH}_{3}\right) ; 7.5- \\
9.1(7 \mathrm{H}, \text { arom }) ; 7.3(1 \mathrm{H}, \text { amide }) ; 3.43(\mathrm{~s} \\
\left.3 \mathrm{H}, \mathrm{OCH}_{3}\right) .\end{array}$ & $58.52(58.53)$ & $4.89(4.91)$ & 17.01(17.06) & 328 & $166-168^{\circ} \mathrm{C}$ \\
\hline
\end{tabular}


Table no 3: Table showing the anticoagulant activity of designed Inhibitors.

\begin{tabular}{|c|c|c|c|}
\hline Sr. No. & $\mathbf{R}^{\prime}$ & $\mathbf{R}$ & $\mathrm{IC}_{50}(\mathrm{mg} / \mathrm{ml})$ \\
\hline 1 & $\mathrm{H}$ & $\mathrm{NH} 2$ & 0.146 \\
\hline 2 & $\mathrm{H}$ & 4- $\mathrm{NO}_{2}$ & 0.561 \\
\hline 3 & $\mathrm{H}$ & $3-\mathrm{NO}_{2}$ & 0.415 \\
\hline 4 & $\mathrm{H}$ & $2-\mathrm{NO}_{2}$ & 0.447 \\
\hline 5 & $\mathrm{H}$ & $4-\mathrm{F}$ & 0.216 \\
\hline 6 & $\mathrm{H}$ & $4-\mathrm{CH}_{3}$ & 0.180 \\
\hline 7 & $\mathrm{H}$ & $2-\mathrm{Cl}$ & 0.256 \\
\hline 8 & $\mathrm{H}$ & $4-\mathrm{OCH}_{3}$ & 0.234 \\
\hline 9 & $\mathrm{H}$ & $3-\mathrm{CH}_{3}$ & 0.221 \\
\hline 10 & $\mathrm{H}$ & $2-\mathrm{CH}_{3}$ & 0.234 \\
\hline 11 & $\mathrm{H}$ & $2-\mathrm{OCH}_{3}$ & 0.211 \\
\hline 12 & $\mathrm{H}$ & $3-\mathrm{OCH}_{3}$ & 0.219 \\
\hline 13 & $5-\mathrm{NO}_{2}$ & $\mathrm{NH} 2$ & 0.332 \\
\hline 14 & $5-\mathrm{NO}_{2}$ & 4- $\mathrm{NO}_{2}$ & NA \\
\hline 15 & $5-\mathrm{NO}_{2}$ & $3-\mathrm{NO}_{2}$ & NA \\
\hline 16 & $5-\mathrm{NO}_{2}$ & $2-\mathrm{NO}_{2}$ & NA \\
\hline 17 & $5-\mathrm{NO}_{2}$ & $4-\mathrm{F}$ & 0.356 \\
\hline 18 & $5-\mathrm{NO}_{2}$ & $4-\mathrm{CH}_{3}$ & 0.260 \\
\hline 19 & $5-\mathrm{NO}_{2}$ & $2-\mathrm{Cl}$ & 0.286 \\
\hline 20 & $5-\mathrm{NO}_{2}$ & $4-\mathrm{OCH}_{3}$ & 0.256 \\
\hline 21 & $5-\mathrm{NO}_{2}$ & $3-\mathrm{CH}_{3}$ & 0.314 \\
\hline 22 & $5-\mathrm{NO}_{2}$ & $2-\mathrm{CH}_{3}$ & 0.278 \\
\hline 23 & $5-\mathrm{NO}_{2}$ & $2-\mathrm{OCH}_{3}$ & 0.311 \\
\hline 24 & $5-\mathrm{NO}_{2}$ & $3-\mathrm{OCH}_{3}$ & 0.415 \\
\hline 25 & \multicolumn{2}{|c|}{ Warfarin } & 0.00123 \\
\hline
\end{tabular}

\section{REFERENCES}

1. O. Klingler, H. Matter, M. Schudok, S. Paul Bajaj, J. Czech, M. Lorenz, H. Peter Nestler, H. Schreudera, P. Wildgoosea .Bio Med Che Lett. 13, 1463, (2003)

2. W.Shrader, A. Kolesnikov, J.Burgess-Henry, R. Rai, J. Hendrix , H.Hu, S.Torkelson ,T. Ton, W. Young, B. Katz, C. Yu, J. Tang, R. Cabuslay , E. Sanford, J. Janca, P. Sprengeler, Bio Med Che Lett, 16,1596, (2006)

3. J. Kohrt, K. Filipski, W. Cody, C. Cai, D. Dudley, C. Van Huis, J. Willardsen, L. Narasimhan, E. Zhang, S. Rapundalo, K. Cork, R. Leadley, J. Edmunds. Bio Med Che Lett. 16, 1060, (2006)

4. K. Zbinden, D. Banner, J. Ackermann, A. Arcy, D. Kirchhofer, Y. Ji, T. Tschopp, S. Wallbaum, L. Weber, Bio Med Che Lett. 15, 817, (2005)

5. S. Bates, J. Weitz . Arter Throm Vas Biol.23,1491,(2003)

6. M. Bhatia, K. Ingale, P.Choudhari, N. Bhatia, R. Sawant Bio Med Che 17, 1654, (2009)

7. P. Choudhari, M. Bhatia Pharmacophore 3 (3), 189, (2012)

8. P. Choudhari, M. Bhatia, N. Bhatia, Med Chem Res 22,976, (2013).

9. Pike, A. Brzozowski, S. Roberts, O. Olsen, E. Persson, PANS 96,925(1999).

10. J. Parlow, R. Kurumbail, R. Stegeman, A. Stevens, W. Stallings, M.South, Bio Med Che Lett. 13,721, ( 2003)

11. E.Ayral, P. Gloanec, G. Bergé, G. Nanteuil, P. Mennecier, A. Rupin , T. Verbeuren, P. Fulcrand, J. Martinez, J. Hernandez . Bio Med Che Lett $19,1386,(2009)$.

12. P. Kotian, R. Krishnan, S. Rowland, Y. El-Kattan, S. Saini, R. Upshaw, S. Bantia, S. Arnold, Y. Babu, P. Chand Bio Med Che 17. 3934, (2009) 